\title{
Corrigendum: What the Heck Is Salience? How Predictive Language Processing Contributes to Sociolinguistic Perception
}

\author{
T. Florian Jaeger ${ }^{1,2,3 *}$ and Kodi Weatherholtz ${ }^{1}$ \\ ${ }^{1}$ Human Language Processing Lab, Department of Brain and Cognitive Sciences, University of Rochester, Rochester, NY, \\ United States, ${ }^{2}$ Department of Computer Science, University of Rochester, Rochester, NY, United States, ${ }^{3}$ Department of \\ Linguistics, University of Rochester, Rochester, NY, United States
}

Keywords: accent, dialect, idiolect, salience, surprisal, prediction, expectation, learning

\section{A corrigendum on}

OPEN ACCESS

Edited and reviewed by: Adriana Hanulikova, Albert Ludwig University of Freiburg,

Germany

*Correspondence:

T. Florian Jaeger

fjaeger@ur.rochester.edu

Specialty section: This article was submitted to

Language Sciences,

a section of the journal

Frontiers in Psychology

Received: 27 March 2017 Accepted: 16 May 2017

Published: 29 May 2017

Citation:

Jaeger TF and Weatherholtz K (2017)

Corrigendum: What the Heck Is Salience? How Predictive Language

Processing Contributes to Sociolinguistic Perception.

Front. Psychol. 8:902.

doi: 10.3389/fpsyg.2017.00902
What the Heck Is Salience? How Predictive Language Processing Contributes to Sociolinguistic Perception

by Jaeger, T. F., and Weatherholtz, K. (2016). Front. Psychol. 7:1115. doi: 10.3389/fpsyg.2016.01115

In the original article, the reference for Shaw et al. (2015) was incorrectly written as:

Shaw, J. A., Catherine, T. B., Karen, E. M., Gerard, D., Bronwen, G. E., Paul, F., et al. (2015). "Effects of short-term exposure to unfamiliar regional accents: Australians' categorization of London and Yorkshire English consonants," in Proceedings of the 15th Australasian International Conference on Speech Science and Technology (Christchurch), 3-5.

It should be:

Shaw, J. A., Best, C. B., Mulak, K. E., Docherty, G. J., Evans, B. G., Foulkes, P., et al. (2015). "Effects of short-term exposure to unfamiliar regional accents: Australians' categorization of London and Yorkshire English consonants," in Proceedings of the 15th Australasian International Conference on Speech Science and Technology (Christchurch), 3-5.

The authors apologize for this error and state that this does not change the scientific conclusions of the article in any way.

The original article has been updated.

Conflict of Interest Statement: The authors declare that the research was conducted in the absence of any commercial or financial relationships that could be construed as a potential conflict of interest.

Copyright $\odot 2017$ Jaeger and Weatherholtz. This is an open-access article distributed under the terms of the Creative Commons Attribution License (CC BY). The use, distribution or reproduction in other forums is permitted, provided the original author(s) or licensor are credited and that the original publication in this journal is cited, in accordance with accepted academic practice. No use, distribution or reproduction is permitted which does not comply with these terms. 